\title{
Pre-service EFL teachers' conceptions of language proficiency: Entry and exit level qualifications
}

\author{
Dinçay Köksal $^{\text {a }}$ (D), Ömer Gökhan Ulum ${ }^{\text {b* }}$ (iD \\ ${ }^{a}$ Çanakkale Onsekiz Mart University, Çanakkale 17020, Turkey \\ ${ }^{b}$ Mersin University, Mersin 2019, Turkey \\ APA Citation: \\ Köksal, D., \& Ulum, Ö. G. (2019). Pre-service EFL teachers' conceptions of language proficiency: entry and exit level qualifications. Journal \\ of Language and Linguistic Studies, 15(2), 484-495. \\ Submission Date:02/10/2018 \\ Acceptance Date:26/01/2019
}

\begin{abstract}
It is clearly observed that EFL teachers' language proficiency has been great concern for researchers in recent decades. However, there seems to be few studies conducted in Turkey to conceive EFL teachers' language proficiency level. Language proficiency refers to competency of performing a language where receptive and productive awareness of language systems are highly emphasized. Any low performance in teachers' language proficiency may endanger the success of students who do not receive effective input from their teachers. Teachers' language performance that includes pragmatic and strategic competence may eventually ease any practice in classroom environment. Although Turkey, where English is a foreign language, introduced English language at an early age starting from the $2^{\text {nd }}$ class of elementary schools, most EFL teachers may still not be sufficiently educated to teach the language. Based on the stated issue, this study inquires the views of pre-service EFL teachers to see their reflections on their university entry and exit levels of English language. A semi-structured interview adopted from Butler's questionnaire titled Self-reported Current and Desired Minimum English Language Proficiency was utilized for the qualitative data. The participants $(\mathrm{N}=35)$ were interviewed about their language proficiency based on the prompts. The findings of the study suggest that ELT departments should be more aware of the weaknesses of the new students and take precautions accordingly.
\end{abstract}

(C) 2019 JLLS and the Authors - Published by JLLS.

Keywords: English as a Foreign Language; pre-service EFL teachers; language; language proficiency; English language proficiency

\section{Introduction}

Teaching a foreign language efficiently necessitates subject knowledge which entails a number of constituents for the foreign language teachers (Shin, 2008). These constituents contain a range of pedagogical, curricular, and cultural awareness besides proficiency in the target language (Pachler, Evans, \& Lawes, 2007). In a foreign language context, teachers' subject knowledge includes language proficiency which refers to 'knowledge competence or ability in the use of a language' as stated by Bachman (1990). Therefore, a foreign language teacher has to own the knowledge of language systems

\footnotetext{
${ }^{*}$ Corresponding author. Tel.: +90-531-791-2434

E-mail address: omergokhanulum@gmail.com
} 
as well as the ability to utilize the language for communicative purposes in diverse situations. Being equipped with the power of the related foreign language is undoubtedly one of the most significant features of a distinguished foreign language teacher (Shin, 2008). For foreign language teachers, proficiency of the target language will ever mean the basis of their occupational determination (Murdoch, 1994). The importance of students' achievements in foreign language learning has necessitated the demand for proficient teachers with advanced foreign language skills. An advanced language teacher embraces the following features (Richards, 2015):

- displaying a proper language model for the learners

- bolstering the use of target language in the classroom setting

- explaining unclear points in English

- supplying learners with examples

- using authentic materials in the classroom setting

- observing learners' language accuracy

- providing feedback properly

- teaching at the right level of difficulty

- providing improvisational teaching for learners.

Butler (2004) also stated the importance of teacher proficiency by hinting on its effects on student success in foreign language learning. Teachers' subject knowledge- a dimension of language proficiency directly affects what is involved in the classroom. Being important for the teacher in controlling several fundamental factors of classroom practices, subject knowledge is an essential determinant of foreign language education (Gibbs \& Holt, 2003; Farrell \& Richards (2007).

Since an inadequate language teacher cannot support a student, a teacher's being equipped with the required language proficiency seems to be more essential than students' acquisition of specific skills in language education. In other words, a teacher with low and unsophisticated subject and content knowledge feels highly inflexible in the classroom setting and hinder the students (Murdoch, 1994). Thus, it has been frequently emphasized that it is vital for language teachers to be efficient enough to teach adequately in the classroom; otherwise a number of problems such as acting in a prescriptive way may occur in the classroom (Farrell \& Richards, 2007).

Today's students are supposed to grasp content while constructing, incorporating and criticizing information from diverse sources, as well as to own good reflective thinking skills and interpersonal communication proficiency. Thus, such student features necessitate teachers who can proficiently respond to student needs (Darling-Hammond, 2006). Sophisticated teachers, who own both intricate and practical knowledge of English, may provide more opportunities for their students (Farrell \& Richards, 2007). The success of language teachers is regarded as the way to student quality, which in turn steer the awareness of teacher education. That is why many teacher education programs worldwide have been reconstructed focusing on the latest theories and practices (Yüksel, 2014).

Although the necessity of EFL teachers' foreign language proficiency has been constantly stressed in many countries, practices, programs, policies, and instruments put into use for building the language skills of foreign language teachers still remain questionable. Judging the proficiency level of foreign language teachers, academics in applied linguistics have boosted notable attention in the related field (Freeman, Katz, Gomez, \& Burns, 2015). Thus, more detailed and practical studies have to be conducted in the related field. Considering all the above mentioned issues that highlight the significance of teachers' language proficiency, this study intends to inquire the views of pre-service EFL teachers about their university entry and exit levels of English language proficiency. Therefore, the following research questions were put forward: 
1. What are the views of pre-service EFL teachers on their English proficiency level at the beginning of the university?

2. What are the views of pre-service EFL teachers on their English proficiency level at the end of the university?

3. Is there any difference between the entry and exit level qualifications of pre-service EFL teachers?

\section{Method}

\subsection{Participants}

The data for the study were collected from pre-service EFL teachers graduated from Çukurova University, Çanakkale Onsekiz Mart University, and Gazi University. These pre-service EFL teachers were selected from the most convenient and accessible institutions. The sample consisted of 35 preservice EFL teachers. High consideration was taken to choose institutions from different regions of Turkey that represent the composition of teachers in the country. In selecting the pre-service EFL teachers, the convenience sampling method was employed as the target population was too large, and thus, not achievable.

\subsection{Instruments and Data Procedure}

The study was carried out through qualitative methods of data collection. The instrument employed in this study was a semi-structured interview adopted from Butler's questionnaire titled Self-reported Current and Desired Minimum English Language Proficiency. The interview was administered to 35 pre-service EFL teachers to specify their views on their English proficiency level when they entered the university, and also the proficiency level when they finished the university. Besides, the interview was employed to understand the extent of difference between the entry and exit level language qualifications. For the coding reliability of the interview on language proficiency levels, Kappa Coefficient for Intercoder Reliability was calculated and it was found that the coding process was highly reliable $(\kappa=.862$, $\mathrm{p}<.001$ ). This study was conducted having resource to the descriptive research design with a view to identifying the perspectives of pre-service EFL teachers pertaining to their English language proficiency level- entry and exit level qualifications.

\section{Data Analysis and Results}

In this section, the results of the study and the findings are clarified based on the data attained from the participants by means of the instrument. They are grouped according to the items of the interview.

\subsection{Results Pertaining to Entry and Exit Level Qualifications for Listening Proficiency}

Table 1 clarifies the results pertaining to the entry and exit level qualifications for listening proficiency. Codes, frequencies, and some remarks of students are presented accordingly. 
Table 1. The Entry and Exit Level Qualifications for Listening Proficiency

\begin{tabular}{|c|c|c|}
\hline Codes & $f$ & Remarks of Students \\
\hline Low university entry level & 25 & $\begin{array}{l}\text { Since we focused on the written based } \\
\text { university entrance exam before university, } \\
\text { my listening level was very poor. }\end{array}$ \\
\hline Intermediate university entry level & 5 & $\begin{array}{l}\text { My listening skill was of intermediate level } \\
\text { both before and after the university. }\end{array}$ \\
\hline High university entry level & 5 & $\begin{array}{l}\text { Having studied at private schools during } \\
\text { both primary and high school educations, my } \\
\text { listening skill was very advanced. }\end{array}$ \\
\hline Low university exit level & 7 & $\begin{array}{l}\text { The lecturers generally have not attended } \\
\text { the courses. Therefore, we couldn't develop } \\
\text { our listening skill during the university. }\end{array}$ \\
\hline Intermediate university exit level & 4 & $\begin{array}{l}\text { My listening skill was of intermediate level } \\
\text { both before and after the university. }\end{array}$ \\
\hline High university exit level & 16 & $\begin{array}{l}\text { During university, since all the courses were } \\
\text { in English, my listening proficiency } \\
\text { developed a lot. }\end{array}$ \\
\hline
\end{tabular}

As can be observed from Table 1, those entering the university at a low listening level $(f=25)$ were observed to be outnumbering those with both intermediate and high listening levels ( $f=5$ for each). Furthermore, as it is easily understood from the table, those with a high exit level of listening skill $(f=$ 16) surpasses the number of those with both low $(f=7)$ and intermediate $(f=4)$ exit levels of listening skill.

Table 2 clarifies the results pertaining to the entry and exit level qualifications for speaking proficiency. Codes, frequencies, and some remarks of students are presented accordingly. 
Table 2. The Entry and Exit Level Qualifications for Speaking Proficiency

\begin{tabular}{|c|c|c|}
\hline Codes & $f$ & Some Remarks of Students \\
\hline Low university entry level & 21 & $\begin{array}{l}\text { Since we focused on the written based } \\
\text { university entrance exam before } \\
\text { university, my speaking level was very } \\
\text { poor. }\end{array}$ \\
\hline Intermediate university entry level & 10 & $\begin{array}{l}\text { Although having limited opportunities to } \\
\text { practice English before the university, I } \\
\text { managed to make it intermediate. }\end{array}$ \\
\hline High university entry level & 4 & $\begin{array}{l}\text { Having worked with tourists gave me the } \\
\text { opportunity to speak a lot. So, I was very } \\
\text { good at speaking English. }\end{array}$ \\
\hline Low university exit level & 2 & $\begin{array}{l}\text { We did not much practice English during } \\
\text { the university years because most of the } \\
\text { instructors usually spoke in Turkish. }\end{array}$ \\
\hline Intermediate university exit level & 7 & $\begin{array}{l}\text { My speaking skill was of intermediate } \\
\text { level both before and after the university. }\end{array}$ \\
\hline High university exit level & 26 & $\begin{array}{l}\text { During the university, since all the } \\
\text { courses were in English, my speaking } \\
\text { proficiency developed a lot. }\end{array}$ \\
\hline
\end{tabular}

It is clearly understood from Table 2 that those entering the university at a low speaking level $(f=$ 21) were seen to be surmounting those with both intermediate $(f=10)$ and high $(f=4)$ speaking levels. Besides, as it is simply displayed in the table, those with a high exit level of speaking level $(f=26)$ highly outnumbers the number of those with both low $(f=2)$ and intermediate $(f=7)$ levels of speaking.

Table 3 clarifies the results pertaining to the entry and exit level qualifications for reading proficiency. Codes, frequencies, and some remarks of students are presented accordingly. 
Table 3. The Entry and Exit Level Qualifications for Reading Proficiency

\begin{tabular}{|c|c|c|}
\hline Codes & $f$ & Some Remarks of Students \\
\hline Low university entry level & 2 & $\begin{array}{l}\text { Since I did not consider it important, my } \\
\text { reading level was very poor when I was at high } \\
\text { school. }\end{array}$ \\
\hline Intermediate university entry level & 13 & $\begin{array}{l}\text { Since we focused on reading at high school, it } \\
\text { developed at an intermediate level. }\end{array}$ \\
\hline High university entry level & 20 & $\begin{array}{l}\text { Since I focused on the university entrance } \\
\text { exam which is totally based on reading and } \\
\text { writing, my reading level was very advanced. }\end{array}$ \\
\hline Low university exit level & 1 & $\begin{array}{l}\text { Since the lecturers of writing based courses did } \\
\text { not come to class, my reading skill never } \\
\text { developed in the university period. }\end{array}$ \\
\hline Intermediate university exit level & 2 & $\begin{array}{l}\text { My reading skill was of intermediate level both } \\
\text { before and after the university. }\end{array}$ \\
\hline High university exit level & 32 & $\begin{array}{l}\text { During the university, since we focused on } \\
\text { reading and analyzing academic texts, our } \\
\text { reading skill extremely developed. }\end{array}$ \\
\hline
\end{tabular}

One can easily understand from Table 3 that those entering the university at a high reading level $(f=$ 20) were seen to be outnumbering those with an intermediate listening level $(f=13)$ and those with a low listening level $(f=2)$. Moreover, it is also clear from the table that those with a high exit level of reading skill $(f=32$ highly surmounts the number of those with both low $(f=1)$ and intermediate $(f=2)$ levels of reading skill.

Table 4 clarifies the results pertaining to the entry and exit level qualifications for writing proficiency. Codes, frequencies, and some remarks of students are presented accordingly. 
Table 4. The Entry and Exit Level Qualifications for Writing Proficiency

\begin{tabular}{|c|c|c|}
\hline Codes & $f$ & Some Remarks of Students \\
\hline Low university entry level & 14 & $\begin{array}{l}\text { Since I did not consider it important, my } \\
\text { writing level was very poor when I was at } \\
\text { high school. }\end{array}$ \\
\hline Intermediate university entry level & 19 & $\begin{array}{l}\text { Since we focused on writing at high school, } \\
\text { it developed at an intermediate level. }\end{array}$ \\
\hline High university entry level & 2 & $\begin{array}{l}\text { We especially wrote lots of compositions at } \\
\text { high school. Therefore, my writing level } \\
\text { was already well developed. }\end{array}$ \\
\hline Intermediate university exit level & 4 & $\begin{array}{l}\text { My writing skill was of intermediate level } \\
\text { both before and after the university. }\end{array}$ \\
\hline High university exit level & 31 & $\begin{array}{l}\text { During the university, my writing skill was } \\
\text { advanced thanks to portfolio assessment. }\end{array}$ \\
\hline
\end{tabular}

Table 4 simply displays that those entering the university at an intermediate writing level $(f=19)$ were seen to be surpassing those with a low writing level $(f=14)$ and those with a high writing level $(f=$ 2 ). Further, the table represents that those with a high exit level of writing skill $(f=31)$ were detected to highly outnumber those with an intermediate university exit level $(f=4)$.

Table 5 clarifies the results pertaining to the entry and exit level qualifications for grammar proficiency. Codes, frequencies, and some remarks of students are presented accordingly. 
Table 5. The Entry and Exit Level Qualifications for Grammar Proficiency

\begin{tabular}{|c|c|c|}
\hline Codes & $f$ & Some Remarks of Students \\
\hline Low university entry level & 1 & $\begin{array}{l}\text { Before the university, we did not much practice } \\
\text { grammar. }\end{array}$ \\
\hline Intermediate university entry level & 7 & $\begin{array}{l}\text { My grammar proficiency was at an } \\
\text { intermediate level, although it could have been } \\
\text { more advanced. However, I did not consider it } \\
\text { important. }\end{array}$ \\
\hline High university entry level & 27 & $\begin{array}{l}\text { As our high school EFL teachers focused } \\
\text { mostly on grammar and the university } \\
\text { entrance exam was based heavily on grammar, } \\
\text { I was highly proficient in it. }\end{array}$ \\
\hline Low university exit level & 4 & $\begin{array}{l}\text { As the only thing that our linguistics lecturer } \\
\text { did was to read a Turkish linguistics book, I } \\
\text { couldn't develop my grammar in any case. }\end{array}$ \\
\hline Intermediate university exit level & 6 & $\begin{array}{l}\text { My grammar skill was of intermediate level } \\
\text { both before and after the university. }\end{array}$ \\
\hline High university exit level & 25 & $\begin{array}{l}\text { Through an interactive grammar education, I } \\
\text { developed myself a lot during university. }\end{array}$ \\
\hline
\end{tabular}

From Table 5, it is simply understood that those entering the university with a high grammar level $(f=27)$ were detected to be surmounting those with both low $(f=1)$ and intermediate $(f=7)$ grammar levels. Additionally, it is also clear from the table that those with a high exit level of grammar $(f=25)$ surpasses the number of those with a low grammar level $(f=4)$ and an intermediate grammar level $(f=$ $6)$.

Table 6 clarifies the results pertaining to the entry and exit level qualifications for vocabulary proficiency. Codes, frequencies, and some remarks of students are presented accordingly. 
Table 6. The Entry and Exit Level Qualifications for Vocabulary Proficiency

\begin{tabular}{|c|c|c|}
\hline Codes & $f$ & 1.1. Some Remarks of Students \\
\hline Low university entry level & 3 & $\begin{array}{l}\text { My vocabulary proficiency was at a poor } \\
\text { level at high school because I didn't know } \\
\text { the required techniques to learn } \\
\text { vocabulary. }\end{array}$ \\
\hline Intermediate university entry level & 18 & $\begin{array}{l}\text { Through memorization, I could only learn } \\
\text { vocabulary at an intermediate level. }\end{array}$ \\
\hline High university entry level & 14 & $\begin{array}{l}\text { Memorizing all the vocabulary required for } \\
\text { the university entrance exam, I learnt } \\
\text { advanced vocabulary. }\end{array}$ \\
\hline Low university exit level & 2 & $\begin{array}{l}\text { The lecturers generally have not attended } \\
\text { the courses. Therefore, we couldn't } \\
\text { develop our vocabulary during the } \\
\text { university. }\end{array}$ \\
\hline Intermediate university exit level & 1 & $\begin{array}{l}\text { My vocabulary knowledge was of } \\
\text { intermediate level both before and after the } \\
\text { university. }\end{array}$ \\
\hline High university exit level & 32 & $\begin{array}{l}\text { By means of learning literary and } \\
\text { academic words, we developed our } \\
\text { vocabulary. }\end{array}$ \\
\hline
\end{tabular}

As can be observed from Table 6, those entering the university at an intermediate vocabulary level $(f=18)$ were seen to be surpassing those with a high vocabulary level $(f=14)$ and those with a low vocabulary level $(f=3)$. Besides, it is also understood from the table that those with a high exit level of vocabulary $(f=32)$ highly outnumbers the number of those with a low vocabulary level $(f=2)$ and intermediate vocabulary level $(f=1)$.

\section{Discussion and Conclusion}

With the aim of compensating for the increasing demand to promote English proficiency, a number of countries where English is used as a foreign language have included English at elementary school programs. So, the quality of EFL teachers has increasingly been a great concern (Butler, 2004). Adjusting EFL courses towards a more academic content is offered as a probable solution for supplying students with a specialized structure based on the requirements and objectives of learning (Vinuesa, 2015), as well as supplying them with occupationally proficient teachers. In this phenomenological study, the views of pre-service EFL teachers from various economical, social, and cultural backgrounds were tried to be investigated by means of a semi-structured interview. Although there were only few 
negative point of views from the respondents, which are not coherent with the standardization requirements of university education (Ceulemans, Simons, \& Struyf, 2012), the overall attitudes were quite reasonable. Generally speaking, it was understood that the pre-service EFL teachers enhanced their four language skills (speaking, listening, reading, and writing) as well as their grammar and vocabulary proficiency during their university education. Moreover, the conclusions made by the respondents are thoroughly clarified as in the followings;

- The listening skill of pre-service EFL teachers was insufficient before university as they were barely exposed to listening tasks during their high school education. In a similar vein, Da Silva (2005) also investigated the views of Brazilian pre-service teachers hold related to four skills in English as a foreign language and consequently she associated the perceptions with pedagogical practice.

- The speaking skill of pre-service EFL teachers was also inadequate before university since they never practiced speaking during high school. Similarly, Dincer and Yesilyurt (2013) investigated pre-service English teachers' views towards the importance they give to speaking skill, and their self-evaluation of their speaking proficiency.

- Since they focused heavily on reading while getting prepared for the university entrance exam, their reading skill was already well-developed before university. In her study, Tercanlioglu (2001) inquired pre-service teachers as readers and future teachers of EFL reading.

- The writing skill of the respondents at the end of high school was also not that much developed compared to that at university as academic writing was heavily focused in the university process. Although there seems to be not many studies based on the writing proficiency of pre-service EFL teachers, in their study, Kurt and Atay (2007) focused on the impact of peer feedback on the writing anxiety of pre-service EFL teachers. Similarly, Jahin (2012) examined the effects of peer feedback on pre-service EFL teachers' writing ability.

- When it comes to grammar and vocabulary proficiency (Butler, 2004), they were also developed during high school since the university entrance exam they studied for is mainly based on grammar and vocabulary performance just like reading.

After the study, some implications were structured;

- ELT departments should be more aware of the weaknesses of the new students and take precautions accordingly.

- High school EFL programs should be rearranged in a way to consider communicative competence.

- High school EFL teachers should give extra importance to the students' weak skills and adapt their teaching activities accordingly.

- Policy makers should consider the weaknesses of the university entrance exam and make improvements in the test validity.

\section{Limitations}

This article includes specific limitations since no study can contain all elements. First, the data of the study were collected from only 35 pre-service EFL teachers from three universities because the target population was too large, and thus, not achievable. Second, the study is restricted to self-reported data which can include possible sources of bias. In other words, the data of this study merely depends on the participants' responses which may not be reflecting their actual language proficiency. Finally, within this study, data collection followed only the phase of a semi-structured interview without using other data collection techniques such as keeping a diary and scenario technique. 


\section{References}

Bachman, L. F. (1990). Fundamental considerations in language testing. Oxford: Oxford University Press.

Butler, Y. G. (2004). What level of English proficiency do elementary school teachers need to attain to teach EFL? Case studies from Korea, Taiwan, and Japan. Tesol Quarterly, 38(2), 245-278.

Ceulemans, C., Simons, M., \& Struyf, E. (2012). Professional standards for teachers: How do they 'work'? An experiment in tracing standardisation in-the-making in teacher education. Pedagogy, Culture \& Society, 20(1), 29-47.

Da Silva, M. (2005). Constructing the Teaching Process from Inside Out: How Pre-Service Teachers Make Sense of Their Perceptions of the Teaching of the Four Skills. TESLEJ, 9(2), n2.

Darling-Hammond, L. (2006). Constructing 21st-Century teacher education. Journal of Teacher Education,57(3), 300-314. doi: 10.1177/0022487105285962

Dincer, A., \& Yesilyurt, S. (2013). Pre-service English teachers' beliefs on speaking skill based on motivational orientations. English Language Teaching, 6(7), 88.

Farrell, TS., \& Richards, J.C. (2007) Teachers' language proficiency. In: Farrell TS (ed.) Reflective Language Teaching: From Research to Practice. London: Continuum, 5566.

Freeman, D., Katz, A., Gomez, G., \& Burns, A. (2015) English for teaching: Rethinking teacher proficiency in the classroom. ELT Journal 69(2): 129-39.

Gibbs, R. \& Holt, R. (2003) The teaching of international languages in New Zealand schools in Years 7 and 8: an evaluation study. Report to the Ministry of Education. Auckland: Auckland University of Technology.

Jahin, J. H. (2012). The Effect of Peer Reviewing on Writing Apprehension and Essay Writing Ability of Prospective EFL Teachers. Australian Journal of Teacher Education, 37(11), n11.

Kurt, G., \& Atay, D. (2007). The Effects of Peer Feedback on the Writing Anxiety of Prospective Turkish Teachers of EFL. Online Submission, 3(1), 12-23.

Murdoch, G. (1994). Language development provisions in teacher training curricula. ELT Journal, 48(3), 253-265.

Pachler, N., Evans, M., \& Lawes, S. (2007). Modern foreign languages: Teaching school subjects 11-19. Routledge.

Richards, JC. (2015) Key Issues in Language Teaching. Cambridge: Cambridge University Press.

Shin, S. (2008). Preparing non-native English speaking ESL teachers. Teacher Development 12, no. 1: 57-65. doi:10.1080/13664530701827749

Tercanlioglu, L. (2001). Pre-service teachers as readers and future teachers of EFL reading. Tesl-ej, 5(3), 1-17.

Vinuesa, M. D. (2015). General English or English for academic purposes? Revising the approaches for core language instruction in English studies. Revista de Lenguas para Fines Específicos, 8, 71-82.

Yüksel, H. G. (2014). Teachers of the future: Perceived teaching competences and visions of pre-service English language teachers. International Journal of Human Sciences, 11(2), 27-39. doi: 10.14687/ijhs.v11i2.2920 


\section{İngilizce öğretmen adaylarının dil yeterlilikleriyle ilgili görüşleri: Üniversite giriş ve çıkış düzeyleri}

\section{Öz}

Son yıllarda İngilizce öğretmenlerinin dil yeterliklerinin araştırmacılar için büyük ilgi uyandırdığı açıktır. Bunun aksine, Türkiye'de bu bağlamda yeterli sayıda çalışma olmadığı gözlemlenmektedir. Dil yeterliliği, dil sistemlerinin algısal ve üretken farkındalığı aracıllğıyla dili icra etmektir. Öğretmenlerin dil yeterliliklerindeki herhangi düşük bir performans öğretmenlerinden etkili girdi almayan öğrencilerin başarısını tehlikeye sokabilir. Öğretmenlerin edimsel ve stratejik becerilerini içeren dil performansı nihai olarak sınıf uygulamalarını kolaylaştııır. İngilizcenin yabancı bir dil olduğu Türkiye'nin ilköğretimde ikinci sınıftan başlayarak İngiliz dilini zorunlu kılmasına rağmen, çoğu İngilizce öğretmeni dil öğretimi için yeteri kadar eğitimli olmayabilir. Bahsedilen bu konuya dayanarak, bu çalışma hizmet öncesi İngilizce öğretmenlerinin İngilizce dil seviyelerinin üniversite giriş ve çıkış farkları hakkındaki görüşlerini irdelemektedir. Butler tarafından geliştirilen Mevcut Ve Arzulanan Asgari İngilizce Dili Yeterliliği adlı sormacadan yararlanılarak oluşturulan yarı yapılandırılmış mülakat soruları nitel veri toplama amacıyla kullanılmıştır. 35 katılımcının dil yeterlilikleriyle ilgili mülakat yapılmıştır. Çalışmanın bulgularından yola çıkarak, hizmet öncesi İngilizce öğretmenlerinin İngilizce gelişimleri için bir dizi öneride bulunulmuştur.

Anahtar sözcükler: Yabancı Dil olarak İngilizce; İngilizce Öğretmen Adayları; Dil; Dil Yeterliliği; İngilizce Yeterliliği

\section{AUTHOR BIODATA}

Prof. Dinçay Köksal is the head of English Language Teaching Department at Çanakkale Onsekiz Mart University, Turkey. His research interests cover language assessment, educational research, language teaching and learning, culture and language, and foreign language education policy.

Dr. Ömer Gökhan Ulum is an academician at Mersin University, Turkey. His research interests cover culture and language, ideology, linguistic hegemony, applied linguistics, pragmatics, discourse analysis, and educational research. 